\title{
The Economic Importance of Plants that are Specific to a Mountain Pastures
}

Zorica VOŞGAN ${ }^{1 *}$, Roxana VIDICAN² ${ }^{2}$ Lucia MIHALESCU ${ }^{1}$, Oana MARE ROŞCA ${ }^{1}$, Beatrice SZILAGYI² Laura IGNAT ${ }^{2}$, Roxana IGNAT ${ }^{2}$

${ }^{1}$ Department of Biology, Technical University of Cluj-Napoca, North University Center of Baia Mare, no.76, Victoriei Street, Baia Mare, Romania;

${ }^{2}$ University of Agricultural Sciences and Veterinary Medicine, Cluj-Napoca

* corresponding author: zori_v13@yahoo.com

Bulletin USAMV series Agriculture 71(2)/2014

Print ISSN 1843-5246; Electronic ISSN 1843-5386

DOI 10.15835/buasvmcn-agr: 10546

\begin{abstract}
Assessing the economic importance of plants present on the mountain pastures, we can distinguish the potential vegetal resources in the context of improving their economic efficiency. In order to determine the vegetal potential in the mountainous region, the analysis of the economic categories in the structure of phytocoenoses was performed, to find some efficient ways of increasing the quality of the pasture. Knowing the valuable or worthless species of grassy carpet of lawns help us make a first picture on the state of normality or degradation of grasslands, by which we would move forward. After analyzing the composition in economic categories of the five phytocenosis of the Gutai Mountains pasture, a decrease of the economic interest species was found. Thus, poor forage value species mainly dominate (28.83 $\%)$, followed by medicinal (20.33\%), melliferous (20.33\%) or even toxic species (12.19\%). In a smaller number found food species, and those for industrial use with a percentage of $10.57 \%$, respectively $9.75 \%$. The quality, i.e. the economic value of the pasture in the mountain area is low, requiring immediate ameliorative measures, to increase the economic potential of the region.
\end{abstract}

Keywords: economic value, grazing, mountain areas.

Introduction. In most grassland ecosystems that are exploited by grazing, modifications in terms of floristic composition appear, their areas being invaded by plant species that deplete their economic value both quantitatively and qualitatively. Mountainous grasslands may be affected by the pedoclimatic conditions, as well as the grazing management. Overgrazing of some mountain pastures and undergrazing of others, due to the depopulation of these environmentally difficult areas, have resulted in degradation of these areas (Zervas, 1998).

Aims and objectives. The purpose of this research is to determine the economic potential of the plant species found in the grassy carpet of mountain pastures, where small ruminants are fed during summer. That way one can find effective ways to enhance the pasture forage quality.

Materials and methods. The research has been carried out on the pasture of the Gutai
Mountains (the South Western region), Maramures County, where five vegetal associations were identified. The economic spectrum of the plant species was stated as consistent with the proposed scheme of Pop (1982).

Results and Discussion. It is known that the numerical share of the species of economic interest is reducing from the hilly floor towards the alpine area (Cristea et al., 2004), where pastures with species of poor economic value are predominant. This was observed after research on the economic spectrum of the plant species of the vegetal associations found on the Gutai Mountains pasture.Meadow area is dominated by different herbaceous vegetal associations as it follows:

1. Violo declinatae-Nardetum Simon, 1966

2. Agrostietum stoloniferae (Ujvárosi 1941) Burduja et al. 1956

3. Calthetum laetae Krajina 1933 
Tab. 1. Distribution of economic categories in the vegetal associations found on the mountain pasture

\begin{tabular}{|c|c|c|c|c|c|c|c|c|c|c|c|}
\hline \multirow{2}{*}{ Vegetal associations } & \multirow{2}{*}{ Al. } & \multicolumn{4}{|c|}{ Fr. } & \multicolumn{3}{|c|}{ Me. } & \multirow{2}{*}{ Md. } & \multirow{2}{*}{ In } & \multirow{2}{*}{$\mathrm{Tx}$} \\
\hline & & 1 & 2 & 3 & 4 & 1 & 2 & 3 & & & \\
\hline 1. & 3 & 3 & 2 & 1 & 1 & 2 & 2 & 1 & 7 & 3 & 4 \\
\hline 2. & 4 & 4 & 1 & 3 & 1 & 2 & 6 & 1 & 7 & 6 & 1 \\
\hline 3. & 1 & 3 & 1 & 1 & - & 1 & 3 & - & 4 & 2 & 4 \\
\hline 4. & 1 & 1 & 1 & 2 & 1 & 1 & 3 & 1 & 2 & 1 & 4 \\
\hline 5. & 3 & 5 & 1 & 1 & - & 2 & - & - & 5 & 1 & 2 \\
\hline
\end{tabular}

Al.-culinary; Fr.-fooder (1-low nutritional value; 2-mediocre nutritional value; 3-good nutritional value; 4-very smooth nutritional value); Me.meliferous (1-low apicola value; 2- mediocre apicola value; 3- high apicola value); Md.- medicinal; In. - industrial; Tx. - toxic.

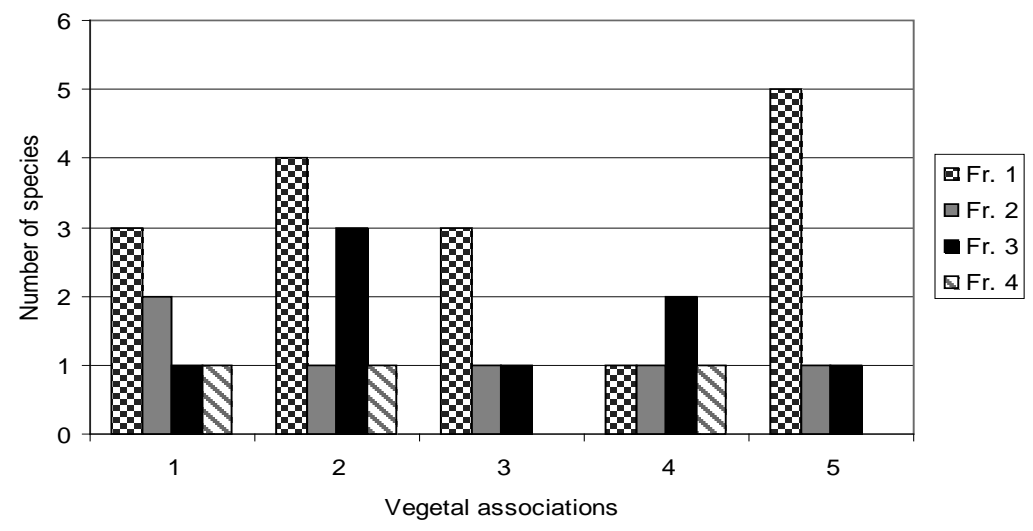

Fig. 1. The nutritive value of forage species in the vegetal associations

4. Scirpetum sylvatici Ralski 1931, Maloch 1935 em. Schwick 1944

5. Campanulo abietinae-Vaccinietum myrtilli (Buia et al. 1962) Boşcaiu 1971

The composition of the economic categories of the five vegetal associations on the Gutai Mountains pasture is included in Table 1.

Theresultsfor all fivestudied plantassociations show that $28.83 \%$ forage species predominate, followed by medicinal and melliferous species with $20.33 \%$. Toxic species are found in a rate of $12.19 \%$ and a smaller number are industrial $(10.57 \%)$ and food species $(9.75 \%)$. Although the economic spectrum reveals the dominance of forage species, subsequent to the analysis relative to the plants nutritional value, forage species with low nutritional value were found to predominate
(Figure 1) in all vegetal associations identified on mountain pastures.

Conclusion: The economic spectrum of the analyzed phytocoenoses shows small differences among them. Forage species with poor nutritional value are predominant, followed by the medicinal, melliferous and toxic plants. Thus, ameliorative measures of improving the quality of pasture it is absolutely necessary to be taken, to enhance the economic potential of the region.

\section{References}

1. Cristea R, Gafta D, Pedrotti F (2004). Fitosociologie. Ed. Presa Universitara Clujeana, Cluj Napoca.

2. Zervas G (1998). Quantifying and optimizing grazing regimes in Greek mountain systems. Journal of Applied Ecology. 35(6):983-986. 